\title{
Anti-inflammatory Activity of the Synthetic Chalcone Derivatives: Inhibition of Inducible Nitric Oxide Synthase-Catalyzed Nitric Oxide Production from Lipopolysaccharide-Treated RAW 264.7 Cells
}

\author{
Young Hoon Kim, Jeongsoo KIM, Haeil PARK, and Hyun Pyo Kiм* \\ College of Pharmacy, Kangwon National University; Chunchon 200-701, Korea. \\ Received January 24, 2007; accepted April 2, 2007
}

\begin{abstract}
Chalcones belong to the flavonoid family from plant origin and some of them possess anti-inflammatory activity. Recently, several natural and synthetic chalcone derivatives were reported to inhibit inducible nitric oxide synthase (iNOS)-catalyzed NO production in cell cultures. In the present study, to find the optimal chemical structures and to elucidate their action mechanisms, 41 synthetic chalcones having the substituent(s) on A- and B-rings were prepared and their effects on iNOS-catalyzed NO production were evaluated using lipopolysaccharide (LPS)-treated RAW 264.7 cells. When simultaneously added with LPS, 2'-methoxy-3,4-dichlorochalcone (Ch15), 2'-hydroxy-6'-methoxychalcone (Ch29), 2'-hydroxy-3-bromo-6'-methoxychalcone (Ch31) and 2'-hydroxy-4', $6^{\prime}$-dimethoxychalcone $(\mathrm{Ch35})$ among the tested compounds potently inhibited NO production $\left(\mathrm{IC}_{50} \mathrm{~s}\right.$, 7.1-9.6 $\mu \mathrm{M})$. The favorable chemical structures were found to be a methoxyl substitution in A-ring at an adjacent position $\left(2^{\prime}\right.$ or $\left.6^{\prime}\right)$ to carbonyl moiety with/without $2^{\prime}$-(or $6^{\prime}$-)hydroxyl group and 3-halogen substitution in B-ring. When the cellular action mechanisms of $\mathrm{Ch} 15, \mathrm{Ch} 31$ and $\mathrm{Ch35}$ were further examined using Western blotting and electrophoretic mobility shift assay, it was revealed that $\mathrm{Ch} 15$ and $\mathrm{Ch} 31$ clearly down-regulated iNOS expression while Ch35 did not. Moreover, Ch15 and Ch31 were proved to suppress the nuclear transcription factor- $K B$ activation. From the results, it is suggested that certain chalcone derivatives potently inhibit iNOS-catalyzed NO production by the different cellular mechanisms, iNOS down-regulation and/or iNOS inhibition, depending on their chemical structures. These chalcone derivatives may possibly be used as lead compounds for developing new anti-inflammatory agents.
\end{abstract}

Key words chalcone; inducible nitric oxide synthase; anti-inflammation; 2'-methoxy-3,4-dichlorochalcone; $2^{\prime}$-hydroxy-4',6'dimethoxychalcone

Natural flavonoids possess anti-inflammatory activity in vitro and in vivo. ${ }^{1,2)}$ As one of their cellular mechanisms, recent investigations have clearly demonstrated that certain flavonoids such as quercetin and wogonin inhibited the transcriptional expression of proinflammatory molecules including interleukin-1, tumor necrosis factor- $\alpha$, cyclooxygenase- 2 and inducible nitric oxide synthase (iNOS). ${ }^{3)}$ Among the proinflammatory molecules affected by flavonoids, iNOS is known to be expressed in several inflammatory conditions and to produce a high amount of NO provoking and maintaining an inflammatory response. ${ }^{4)}$ Thus, it is significant that inhibition of iNOS activity and/or down-regulation of iNOS expression may lead to anti-inflammation in certain disease conditions.

Chalcone $\left(\mathrm{C}_{6}-\mathrm{C}_{3}-\mathrm{C}_{6}\right.$ compound $)$ is one of the subgroups of the flavonoid family. Previously, several chalcone derivatives were demonstrated to inhibit iNOS-catalyzed NO production. The examples are $3,3^{\prime}, 4,4^{\prime}, 5,5^{\prime}$-hexamethoxychalcone, ${ }^{5)}$ broussochalcone A $\left(2^{\prime}, 3,4,4^{\prime}\right.$-tetrahydroxy-5' ${ }^{\prime}$-isoprenylchalcone), ${ }^{6)}$ dimethylaminochalcones, ${ }^{7)}$ isoliquiritigenin $\left(2^{\prime}, 4,4^{\prime}\right.$-trihydroxychalcone $){ }^{8)} \quad 2^{\prime}$-hydroxy-4'-methoxychalcone, 2',4-dihydroxy-4'-methoxychalcone, 2',4-dihydroxy$6^{\prime}$-methoxychalcone, ${ }^{9)} 2^{\prime}$-hydroxy-3,4-dichlorochalcone, 3,5di-tert-butyl-2',4,5' -trihydroxychalcone, 2',5'-dimethoxy-4hydroxychalcone ${ }^{10)}$ and cardamonin $\left(2^{\prime}, 4^{\prime}\right.$-dihydroxy- $6^{\prime}$ methoxychalcone). ${ }^{11)}$ These compounds were shown to reduce iNOS-catalyzed NO production and a part of the cellular mechanism is suggested to be iNOS down-regulation. However, these previous studies have been far from complete, although several suggestions concerning the optimized chemical structures were made from structure-activity stud- ies. $^{7,10)}$ Therefore, in this investigation, 41 synthetic chalcones having halogen, hydroxyl and/or methoxyl groups were prepared and their inhibitory activities of iNOS-catalyzed NO production including the cellular action mechanisms were investigated using a mouse macrophage-like cell line, RAW 264.7 cell.

\section{MATERIALS AND METHODS}

Chemicals 2-Amino-5,6-dihydro-6-methyl-4H-1,3-thiazine hydrochloride (AMT, iNOS inhibitor) was purchased from Tocris Cookson (U.K.). (3-(4,5-Dimethylthiazol-2-yl)2,5-diphenyltetrazolium bromide (MTT) and lipopolysaccharide (LPS, Escherichia coli 0127:B8) were purchased from Sigma Chem. (St. Louis, MO, U.S.A.). Dulbecco's modified Eagle's medium (DMEM) and other cell culture reagents including FBS were products of Gibco BRL (Grand Island, NY, U.S.A.). The protein assay kit was purchased from BioRad Lab. (Hercules, CA, U.S.A.).

General Procedure for Preparation of the Chalcone Derivatives All chalcone derivatives were prepared as described previously. ${ }^{12)}$ Briefly, to a two necked flask equipped with a reflux condenser and a magnetic stirrer were added acetophenones (acetophenone for $\mathrm{Ch} 1-\mathrm{Ch} 8,2^{\prime}$-hydroxyacetophenone for $\mathrm{Ch} 9-\mathrm{Ch} 15,4^{\prime}$-hydroxyacetophenone for Ch16, 2',4'-dihdroxyacetophenone for Ch17-Ch26; 2',5'dihydroxyacetophenone for $\mathrm{Ch} 27$ and $\mathrm{Ch} 28 ; 2^{\prime}, 6^{\prime}$-dihydroxyacetophenoe for Ch29-Ch34 and $2^{\prime}, 4^{\prime}, 6^{\prime}$-trihydroxyacetophenone for $\mathrm{Ch} 35-\mathrm{Ch} 41), \mathrm{K}_{2} \mathrm{CO}_{3}$ and acetone. To the reaction mixture was added dimethyl sulfate through the condenser over a $20 \mathrm{~min}$ period with vigorous stirring. The 
methylation was continued under refluxing conditions for $2 \mathrm{~h}$, monitoring by TLC with a solvent system of chloroform: methanol $(20: 1)$. After removing potassium carbonate by filtration, the solvent was distilled off. The crude solid was washed with water, and crystallized from methanol to yield the products $\left(2^{\prime}\right.$-hydroxy- $4^{\prime}$-methoxyacetophenone from $2^{\prime}, 4^{\prime}$-dihydroxyacetophenone; $2^{\prime}$-hydroxy$5^{\prime}$-methoxyacetophenone from $2^{\prime}, 5^{\prime}$-dihydroxyacetophenone; $2^{\prime}$-hydroxy-4',6'-dimethoxyacetophenone from 2',4',6'-trihydroxyacetophenone). $2^{\prime}$-Hydroxyacetophenone analogs $\left(2^{\prime}-\right.$ hydroxy-4'-methoxyacetophenone, 2 '-hydroxy-5'-methoxyacetophenone, $2^{\prime}$-hydroxy- $4^{\prime}, 6^{\prime}$-dimethoxyacetophenone) and arylaldehyde were dissolved in methanol with stirring. Potassium hydroxide was added in several portions to give a blood-red solution. The resulting solution was stirred for $8-12 \mathrm{~h}$, during which chalcones were precipitated as the potassium salt. The solution/suspensions were poured into cold $1 \mathrm{~N} \mathrm{HCl}(10 \mathrm{ml})$, and further concentrated $\mathrm{HCl}$ was added until the solutions became acidic. The resulting precipitated solids were filtered, washed with water, and recrystallized from methanol to give the corresponding chalcones. The physical and analytical data for the new compounds based on SciFinder structure search were as follows;

Ch11: ${ }^{1} \mathrm{H}-\mathrm{NMR}\left(400 \mathrm{MHz}, \mathrm{CDCl}_{3}\right) ; \delta 12.73(\mathrm{~s}, 1 \mathrm{H}, \mathrm{OH})$, $7.87-7.93\left(\mathrm{~m}, 2 \mathrm{H}, J=1.5,8.0,15.5 \mathrm{~Hz}, \mathrm{H} 6^{\prime}, \mathrm{H} \beta\right), 7.68$ $7.72(\mathrm{~m}, 2 \mathrm{H}, \mathrm{H} 2, \mathrm{H} 6), 7.61-7.65(\mathrm{~d}, 1 \mathrm{H}, J=15.5 \mathrm{~Hz}, \mathrm{H} \alpha)$, $7.50-7.54\left(\mathrm{~m}, 1 \mathrm{H}, \mathrm{H} 4^{\prime}\right), 7.28-7.30(\mathrm{~d}, 2 \mathrm{H}, J=8.2 \mathrm{~Hz}, \mathrm{H} 3$, H5), $7.03-7.06\left(\mathrm{dd}, 1 \mathrm{H}, J=0.9,8.4 \mathrm{~Hz}, \mathrm{H3}{ }^{\prime}\right), 6.94-6.98$ $\left(\mathrm{m}, 1 \mathrm{H}, \mathrm{H} 5^{\prime}\right) ;{ }^{13} \mathrm{C}-\mathrm{NMR}\left(100 \mathrm{MHz}, \mathrm{CDCl}_{3}\right): \delta 193.83$ $(\mathrm{C}=\mathrm{O}), 164.05$ (C-2'), 151.23 (C-4), 143.98 (C- $\beta), 137.03$ $\left(\mathrm{C}-4^{\prime}\right), 133.58\left(\mathrm{C}-6^{\prime}\right), 130.51$ (C-2, C-6), 130.03 (C-1), $122.05\left(\mathrm{OCF}_{3}\right), 121.64\left(\mathrm{C}-5^{\prime}\right), 121.38\left(\mathrm{C}-1^{\prime}\right), 120.31(\mathrm{C}-\alpha)$, 119.35 (C-3'), 119.14 (C-3, C-5); mp 83-85 ${ }^{\circ} \mathrm{C} ; m / z 309$ $\left(\mathrm{M}^{+}, 70\right), 308$ (100), 307 (95), 188 (68), 147 (94), 121 (94), 120 (96), $101(70)$.

Ch15: ${ }^{1} \mathrm{H}-\mathrm{NMR}\left(400 \mathrm{MHz}, \mathrm{CDCl}_{3}\right): \delta 7.63-7.65(\mathrm{dd}, 2 \mathrm{H}$, $\left.J=1.8,8.4 \mathrm{~Hz}, \mathrm{H} 2, \mathrm{H}^{\prime}\right), 7.45-7.54(\mathrm{~m}, 3 \mathrm{H}, \mathrm{H} \beta, \mathrm{H} 5, \mathrm{H} 6)$, $7.35-7.41\left(\mathrm{~m}, 2 \mathrm{H}, \mathrm{H} \alpha, \mathrm{H}^{\prime}\right), 7.03-7.06(\mathrm{t}, 1 \mathrm{H}, J=7.5 \mathrm{~Hz}$, $\left.\mathrm{H}^{\prime}\right), 6.99-7.02$ (d, 1H, J=8.4 Hz, H3' $), 3.91$ (s, 3H, OMe); ${ }^{13} \mathrm{C}-\mathrm{NMR}\left(100 \mathrm{MHz}, \mathrm{CDCl}_{3}\right): \delta 192.52(\mathrm{C}=\mathrm{O}), 158.69(\mathrm{C}-$ $\left.2^{\prime}\right), 140.29$ (C- $\left.\beta\right), 135.72\left(\mathrm{C}-4^{\prime}\right), 134.37$ (C-1), 133.78 (C-3), 133.57 (C-4), 131.27 (C-1'), 130.95 (C-5), 130.18 (C-2), 129.23 (C-6), $128.91\left(\mathrm{C}-6^{\prime}\right), 127.79\left(\mathrm{C}-5^{\prime}\right), 121.28(\mathrm{C}-\alpha)$, $112.07\left(\mathrm{C}-3^{\prime}\right), 56.22(\mathrm{OMe}) ; \mathrm{mp} 74-76^{\circ} \mathrm{C} ; \mathrm{m} / z 306\left(\mathrm{M}^{+}\right.$, 32), 147 (60), 136 (38), 135 (100), 121 (29), 120 (45), 92 (35), 77 (56).

Ch28: ${ }^{1} \mathrm{H}-\mathrm{NMR}\left(400 \mathrm{MHz}, \mathrm{CDCl}_{3}\right): \delta 12.23(\mathrm{~s}, 1 \mathrm{H}, \mathrm{OH})$, $7.76-7.79(\mathrm{~d}, 1 \mathrm{H}, J=15.5 \mathrm{~Hz}, \mathrm{H} \beta), 7.728-7.733(\mathrm{~d}, 1 \mathrm{H}$, $J=1.8 \mathrm{~Hz}, \mathrm{H} 2), 7.45-7.56(\mathrm{~m}, 3 \mathrm{H}, \mathrm{H} \alpha, \mathrm{H} 5, \mathrm{H} 6), 7.31-$ $7.32\left(\mathrm{~d}, 1 \mathrm{H}, J=3.0 \mathrm{~Hz}, \mathrm{H6}^{\prime}\right), 7.14-7.17(\mathrm{dd}, 1 \mathrm{H}, J=3.0$, $\left.9.1 \mathrm{~Hz}, \mathrm{H} 3^{\prime}\right), 6.97-6.99\left(\mathrm{~d}, 1 \mathrm{H}, J=9.1 \mathrm{~Hz}, \mathrm{H} 4^{\prime}\right), 3.85(\mathrm{~s}$, $3 \mathrm{H}, \mathrm{OMe}) ;{ }^{13} \mathrm{C}-\mathrm{NMR}\left(100 \mathrm{MHz}, \mathrm{CDCl}_{3}\right) ; \delta 193.17(\mathrm{C}=\mathrm{O})$, $158.44\left(\mathrm{C}-2^{\prime}\right), 152.20\left(\mathrm{C}^{\prime} 5^{\prime}\right), 143.04(\mathrm{C}-\beta), 135.24(\mathrm{C}-1)$, 135.00 (C-3), 133.85 (C-4), 131.45 (C-5), 130.31 (C-2), 128.14 (C-6), $124.60\left(\mathrm{C}-4^{\prime}\right), 122.12\left(\mathrm{C}-3^{\prime}\right), 119.89\left(\mathrm{C}-1^{\prime}\right)$, $119.83(\mathrm{C}-\alpha), 113.28$ (C-6'), 56.60 (OMe); mp 127$130{ }^{\circ} \mathrm{C} ; \mathrm{m} / \mathrm{z} 324\left(\mathrm{M}^{+}, 36\right), 323$ (15), 322 (52), 177 (21), 151 (16), 150 (100), 135 (15).

Ch30: ${ }^{1} \mathrm{H}-\mathrm{NMR}\left(400 \mathrm{MHz}, \mathrm{CDCl}_{3}\right): \delta 13.10(\mathrm{~s}, 1 \mathrm{H}, \mathrm{OH})$, $7.80-7.84(\mathrm{~d}, 1 \mathrm{H}, J=5.6 \mathrm{~Hz}, \mathrm{H} \beta), 7.68-7.72(\mathrm{~d}, 1 \mathrm{H}$, $J=15.6 \mathrm{~Hz}, \mathrm{H} \alpha), 7.52-7.54(\mathrm{~m}, 2 \mathrm{H}, \mathrm{H} 2, \mathrm{H} 6), 7.44-7.46$ (d, $2 \mathrm{H}, J=8.5 \mathrm{~Hz}, \mathrm{H} 3, \mathrm{H} 5), 7.33-7.37(\mathrm{t}, 1 \mathrm{H}, J=8.4 \mathrm{~Hz}$, $\left.\mathrm{H} 4^{\prime}\right), 6.60-6.62\left(\mathrm{~m}, 1 \mathrm{H}, \mathrm{H} 5^{\prime}\right), 6.40-6.43(\mathrm{~d}, 1 \mathrm{H}, J=$ $\left.8.5 \mathrm{~Hz}, \mathrm{H}^{\prime}\right) ;{ }^{13} \mathrm{C}-\mathrm{NMR} \quad\left(100 \mathrm{MHz}, \mathrm{CDCl}_{3}\right): \delta 194.61$ $(\mathrm{C}=\mathrm{O}), 165.32\left(\mathrm{C}-2^{\prime}\right), 161.37\left(\mathrm{C}-6^{\prime}\right), 141.81(\mathrm{C}-\beta), 136.55$ (C-4'), 134.66 (C-1), 132.57 (C-3, C-5), 130.20 (C-2, C-6), $128.56(\mathrm{C}-\alpha), 124.92$ (C-4), $112.27\left(\mathrm{C}-1^{\prime}\right), 111.39\left(\mathrm{C}-3^{\prime}\right)$, 101.98 (C-5'), 56.40 (OMe); mp 125-127 ${ }^{\circ} \mathrm{C} ; \mathrm{m} / \mathrm{z} 334\left(\mathrm{M}^{+}\right.$, 86), 333 (89), 332 (89), 331 (86), 177 (100), 151 (66), 150 (78), $102(51)$.

Ch31: ${ }^{1} \mathrm{H}-\mathrm{NMR}\left(400 \mathrm{MHz}, \mathrm{CDCl}_{3}\right): \delta 13.05(\mathrm{~s}, 1 \mathrm{H}, \mathrm{OH})$, $7.82-7.86(\mathrm{~d}, 1 \mathrm{H}, J=15.6 \mathrm{~Hz}, \mathrm{H} \beta), 7.75-7.76(\mathrm{t}, 1 \mathrm{H}$, $J=1.5 \mathrm{~Hz}, \mathrm{H} 2), 7.69-7.73(\mathrm{~d}, 1 \mathrm{H}, J=15.6 \mathrm{~Hz}, \mathrm{H} \alpha), 7.52$ $7.55(\mathrm{dd}, 2 \mathrm{H}, J=1.7,7.8 \mathrm{~Hz}, \mathrm{H} 4, \mathrm{H} 6), 7.37-7.41(\mathrm{t}, 1 \mathrm{H}$, $\left.J=8.4 \mathrm{~Hz}, \mathrm{H} 4^{\prime}\right), 7.28-7.32(\mathrm{t}, 1 \mathrm{H}, J=7.8 \mathrm{~Hz}, \mathrm{H} 5), 6.63-$ $6.65\left(\mathrm{dd}, 1 \mathrm{H}, J=0.7,8.4 \mathrm{~Hz}, \mathrm{H} 5^{\prime}\right), 6.44-6.46(\mathrm{~d}, 1 \mathrm{H}$, $\left.J=8.2 \mathrm{~Hz}, \mathrm{H} 3^{\prime}\right), 3.98$ (s, 3H, OMe); ${ }^{13} \mathrm{C}-\mathrm{NMR}(100 \mathrm{MHz}$, $\left.\mathrm{CDCl}_{3}\right): \delta 194.57(\mathrm{C}=\mathrm{O}), 165.31\left(\mathrm{C}-2^{\prime}\right), 161.40\left(\mathrm{C}-6^{\prime}\right)$, $141.32(\mathrm{C}-\beta), 137.91(\mathrm{C}-1), 136.63\left(\mathrm{C}-4^{\prime}\right), 133.38(\mathrm{C}-2)$, 131.37 (C-4), 130.83 (C-5), 129.34 (C- $\alpha), 127.53$ (C-6), 123.45 (C-3), $112.28\left(\mathrm{C}-1^{\prime}\right), 111.41\left(\mathrm{C}-3^{\prime}\right), 101.98\left(\mathrm{C}-5^{\prime}\right)$, 56.46 (OMe); mp 127-130 ${ }^{\circ} \mathrm{C} ; m / z 334\left(\mathrm{M}^{+}, 37\right), 333$ (35), 332 (38), 331 (28), 177 (100), 151 (27), 102 (21).

RAW 264.7 Cell Culture and Measurement of NO Concentration RAW 264.7 cells obtained from the American Type Culture Collection were cultured with DMEM supplemented with $10 \%$ FBS and $1 \%$ antibiotics under $5 \% \mathrm{CO}_{2}$ at $37^{\circ} \mathrm{C}$ and activated with LPS according to the previously described procedures. ${ }^{13)}$ In brief, the cells were plated in 96well plates $\left(2 \times 10^{5}\right.$ cells/well). After pre-incubation for $12 \mathrm{~h}$, the test compounds including the chalcones and LPS $(1 \mu \mathrm{g} / \mathrm{ml})$ were added and the cells were incubated for $24 \mathrm{~h}$, unless otherwise specified. Test compounds were dissolved in DMSO on the day of the experiment and diluted with serum-free DMEM into appropriate concentrations. Final concentration of DMSO was adjusted to $0.1 \%(\mathrm{v} / \mathrm{v})$. Control groups also received the same amount of DMSO. Cell viability was assessed with MTT assay based on the experimental procedures described previously. ${ }^{14)}$ For a determination of $\mathrm{NO}$ concentration, the stable conversion product of $\mathrm{NO}$, nitrite $\left(\mathrm{NO}_{2}^{-}\right)$, was measured using Griess reagent [1:1 mixture $(\mathrm{v} / \mathrm{v})$ of $1 \%$ sulfanilamide in $\mathrm{H}_{3} \mathrm{PO}_{4}$ and $0.1 \%$ naphthylethylenediamine dihydrochloride in $\left.5 \% \mathrm{H}_{3} \mathrm{PO}_{4}\right]$. Optical density was measured with a microplate reader (Spectra Max, Molecular Devices) at $550 \mathrm{~nm}$. In order to determine the direct inhibitory effects of the test compounds of iNOS enzyme on cell level, the cells were incubated with LPS $(1 \mu \mathrm{g} / \mathrm{ml})$ for $24 \mathrm{~h}$ to fully induce iNOS and completely washed with serum-free DMEM three times. Then, the test compounds were added without LPS and the cells were incubated for another $24 \mathrm{~h}$. From the medium, NO concentration was measured as described above. For measuring the iNOS inhibitory activity of the chalcones on enzyme level, pre-activated RAW cells were homogenized and the homogenate was used as an enzyme source. The homogenate $(30 \mu \mathrm{l})$ and the test compounds were incubated at $37^{\circ} \mathrm{C}$ for $30 \mathrm{~min}$, and $\mathrm{NO}$ concentration was determined with a nitrate/nitrite colorimetric assay kit (LDH method, Cayman Chem.) according to the manufacturer's recommendation.

Western Blotting Analysis For measuring the protein level of iNOS, the Western blotting technique was used. ${ }^{13)}$ RAW cells were cultured in 6 -well plates $\left(5 \times 10^{6}\right.$ cells/well $)$ 
in the presence or absence of LPS $(1 \mu \mathrm{g} / \mathrm{ml})$ with/without the test compounds for $20 \mathrm{~h}$. After washing twice with PBS buffer, the cells were harvested and lysed with protein extraction solution (iNtRON Biotech., Korea). After centrifugation at $13000 \mathrm{~g}$ for $10 \mathrm{~min}$, the supernatant was obtained and mixed with $5 \mathrm{X}$ sample buffer. Using $8 \%$ polyacrylamide gel, electrophoresis was carried out and bands were blotted to PVDF membranes. iNOS antibody (Sigma Chem., St. Louis, MO, U.S.A.) was incubated and the bands were visualized with HRP-linked secondary antibody (Cell Signaling, Danvers, MA, U.S.A.) and chemiluminescent reagent (Amersham, U.K.).

Reverse Transcriptase-Polymerase Chain Reaction (RT-PCR) RAW cells were cultured in 6 -well plates $(5 \times$ $10^{6}$ cells/well) in the presence or absence of LPS $(1 \mu \mathrm{g} / \mathrm{ml})$ with/without the test compounds for $5 \mathrm{~h}$. The cells were collected and homogenized in RLT buffer containing $1 \% \beta$-mercaptoethanol for $30 \mathrm{~s}$. Total RNA was extracted using an RNeasy mini kit (Qiagen, Germany) according to the supplier's protocol. The concentration of RNA content was determined by measuring the absorbance at 260 and $280 \mathrm{~nm}$. cDNAs were synthesized using RT reaction at $42^{\circ} \mathrm{C}, 50 \mathrm{~min}$ and $99^{\circ} \mathrm{C}, 5 \mathrm{~min}$ in a Gene Cycler thermal cycler (Bio-Rad, Hercules, CA, U.S.A.). Primers were synthesized on the basis of the repeated mouse cDNA sequence for iNOS and G3PDH. The primer sequences used for PCR were as follows: iNOS sense, $5^{\prime}$-CCC TTC CGA AGT TTC TGG CAG CAG C-3', antisense, 5'-GGC TGT CAG AGC CTC GTG GCT TTG G-3', 469 bp; G3PDH sense, 5' -TGA AGG TCG GTG TGA ACG GAT TTG GC-3', antisense, 5'-CAT GTA GGC CAT GAG GTC CAC CAC-3', 983 bp. PCR was carried out for 30 cycles under saturation, in $25 \mu \mathrm{l}$ reaction mixture. After amplification, $10 \mu \mathrm{l}$ of reaction mixture was analyzed on $1.5 \%$ agarose gel electrophoresis. The bands were visualized by ethidium bromide staining for $10 \mathrm{~min}$.

Electrophoretic Mobility Shift Assay Nuclear extracts from RAW cells were prepared as previously described. ${ }^{15)}$ In brief, the cells were incubated in the presence or absence of LPS and the test compounds for $30 \mathrm{~min}$. To prepare nuclear fractions, the cells were washed twice with PBS, harvested and resuspended in $400 \mu \mathrm{l}$ of buffer A (10 mM HEPES, $10 \mathrm{~mm} \mathrm{KCl,} \mathrm{0.1} \mathrm{mM} \mathrm{EDTA,} 1 \mathrm{~mm}$ DTT, $0.5 \mathrm{~mm}$ PMSF, pH 7.9) for $15 \mathrm{~min}$ on ice. After 10\% NP-40 (25 $\mu \mathrm{l})$ was added, the tubes were vortexed vigorously for $10 \mathrm{~s}$. The nuclei were collected by centrifugation at $5000 \mathrm{rpm}$ for $3 \mathrm{~min}$ and lysed in buffer B (20 mm HEPES, $0.4 \mathrm{~m} \mathrm{NaCl}, 1 \mathrm{~mm}$ EDTA, $1 \mathrm{~mm}$ DTT, 1 mм PMSF, pH 7.9). Nuclear transcription factor- $\kappa \mathrm{B}$ $(\mathrm{NF}-\kappa \mathrm{B})$ consensus oligonucleotide (Promega, Madison, WI, U.S.A.) was phosphorylated by $\mathrm{T} 4$ polynucleotide kinase with $10 \mu \mathrm{Ci}$ of $\left[\gamma^{32} \mathrm{P}\right]$ ATP $(3000 \mathrm{Ci} / \mathrm{mmol})$ at $37^{\circ} \mathrm{C}$ for $10 \mathrm{~min}$. Unincorporated oligonucleotides were removed by Microspin G-25 column (Amersham, U.K.). Nuclear extract containing $5 \mu \mathrm{g}$ protein was incubated with ${ }^{32} \mathrm{P}$-labeled NF$\kappa \mathrm{B}$ consensus oligonucleotide in gel shift binding buffer at room temperature for $20 \mathrm{~min}$. The incubation mixture was subjected to electrophoresis on a $4 \%$ polyacrylamide gel in TBE buffer $(0.5 \mathrm{X})$ at $300 \mathrm{~V}$. The gel was dried and exposed to X-ray film overnight at $-70^{\circ} \mathrm{C}$.

Experimental Data All data in the present investigation represent arithmetic means from duplicate experiments.

\section{RESULTS AND DISCUSSION}

It is well characterized that LPS treatment of RAW 264.7 cells induces iNOS to produce high concentrations of NO. In one typical experiment, LPS treatment $(1 \mu \mathrm{g} / \mathrm{ml})$ increased NO concentration of $26.4 \mu \mathrm{M}$ from the basal level of $0.6 \mu \mathrm{M}$ for a $24 \mathrm{~h}$ incubation period. Under this condition, the chalcone derivatives $(10 \mu \mathrm{M})$ were added simultaneously with LPS, and their inhibitory activities against iNOS-catalyzed NO production were examined. As demonstrated in Table 1, several chalcone derivatives including $\mathrm{Ch} 7, \mathrm{Ch} 8, \mathrm{Ch} 9, \mathrm{Ch} 15$, Ch16, Ch23, Ch25, Ch29, Ch31, Ch35, Ch37 and Ch41 showed a considerable inhibition (more than $40 \%$ inhibition at $10 \mu \mathrm{M})$. In particular, Ch15, Ch29, Ch31, Ch35 and Ch37 showed potent inhibitory activity (more than 60\% inhibition at $10 \mu \mathrm{M})$. Some of these chalcone derivatives were rechecked to obtain their $\mathrm{IC}_{50}$ values at the noncytotoxic concentration ranges (Fig. 1), and $\mathrm{Ch} 15, \mathrm{Ch} 29, \mathrm{Ch} 31$ and $\mathrm{Ch} 35$ have their $\mathrm{IC}_{50} \mathrm{~s}$ of less than $10 \mu \mathrm{M}$, Ch15 being the most potent (Fig. 2, Table 1). The potent ones among the conventional chalcones that have the substituent(s) on the molecule only with hydroxyl and/or methoxyl group were Ch29 and Ch35. Considering the $\mathrm{IC}_{50} \mathrm{~s}$ of other conventional chalcones published previously, these chalcones have a higher potency of inhibition against iNOS-catalyzed NO production. It is, however, noteworthy that some of these synthetic compounds having halogen(s) at B-ring 3- or 3,4-positions were cytotoxic to RAW cells at the concentrations of higher than $25 \mu \mathrm{M}$. By MTT assay, Ch7, Ch9, Ch15, Ch16 and Ch31 at $25 \mu \mathrm{M}$ showed $3.4 \%, 11.1 \%, 50.8 \%, 20.2 \%$ and $53.6 \%$ reductions of viability, respectively.

The following structure-activity relationships were found. C-4 substitution with halogen, methyl, methoxyl or phenyl group did not considerably enhance the inhibitory activity of NO production (Ch1 vs. Ch2-Ch6). Otherwise, C-3 substitution with halogen or methoxyl group caused considerable inhibition of iNOS-catalyzed NO production. For example, 3-bromo substitution (Ch8, Ch9) gave a higher activity, compared to the unsubstituted chalcone (Ch1). Ch31 was slightly more potent than Ch29. The high inhibitory activity appeared in the compounds having 3,4-dichloro substitutions ( $\mathrm{Ch} 7$, Ch15, Ch16, Ch23, Ch41) except Ch28. Among the chalcones having dimethoxyl substitutions at B-ring, 3,4-dimethoxylation gave a higher activity than the compounds having 2,3- or 2,4-dimethoxylation (Ch13 vs. Ch12 and Ch14, Ch25 vs. Ch24 and Ch26). It was also found that A-ring $2^{\prime}$-hydroxyl and $6^{\prime}$-methoxyl groups with/without $4^{\prime}$-methoxyl substitution were favorable as in $\mathrm{Ch} 29-\mathrm{Ch} 33$, Ch35-Ch38 and Ch41, whereas $2^{\prime}$-hydroxyl and $4^{\prime}$-methoxyl substitutions (Ch17Ch21) or 2'-hydroxyl and 5'-methoxyl substitutions (Ch27, Ch28) were not. Based on the most potent chalcones found (Ch15, Ch29, Ch31, Ch35), the optimum chemical structures were suggested to be a methoxyl substitution in A-ring at an adjacent position $\left(2^{\prime}\right.$ or $\left.6^{\prime}\right)$ to carbonyl moiety with/without $2^{\prime}$ - (or 6'-)hydroxyl group and 3-halogen substitution in Bring. The observation that $2^{\prime}$-substitution with hydroxyl or methoxyl group is important was also demonstrated by the previous reports. ${ }^{9,10,16)}$ In addition, the previous finding of the inactive nature of $2^{\prime}$-hydroxy-4, $4^{\prime}$-dimethoxychalcone $(\mathrm{Ch} 34)^{9)}$ coincided with our results. However, in our experiment, 2'-hydroxy-4'-methoxychalcone (Ch17) did not show 
Table 1. Inhibition of NO Production from LPS-Treated RAW 264.7 Cells by the Synthetic Chalcones

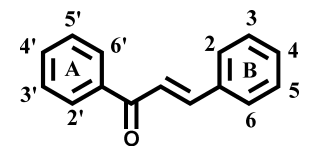

\begin{tabular}{|c|c|c|c|c|c|c|c|c|c|}
\hline & $2^{\prime}$ & $4^{\prime}$ & $5^{\prime}$ & $6^{\prime}$ & 2 & 3 & 4 & Inhibition $(\%)^{a)}$ & $\mathrm{IC}_{50}(\mu \mathrm{M})$ \\
\hline Ch1 & $\mathrm{H}$ & $\mathrm{H}$ & $\mathrm{H}$ & $\mathrm{H}$ & $\mathrm{H}$ & $\mathrm{H}$ & $\mathrm{H}$ & $-^{b)}$ & \\
\hline Ch2 & $\mathrm{H}$ & $\mathrm{H}$ & $\mathrm{H}$ & $\mathrm{H}$ & $\mathrm{H}$ & $\mathrm{H}$ & $\mathrm{Br}$ & - & \\
\hline $\mathrm{Ch} 3$ & $\mathrm{H}$ & $\mathrm{H}$ & $\mathrm{H}$ & $\mathrm{H}$ & $\mathrm{H}$ & $\mathrm{H}$ & $\mathrm{Cl}$ & - & \\
\hline $\mathrm{Ch} 4$ & $\mathrm{H}$ & $\mathrm{H}$ & $\mathrm{H}$ & $\mathrm{H}$ & $\mathrm{H}$ & $\mathrm{H}$ & $\mathrm{CH}_{3}$ & $17.2^{c)}$ & \\
\hline Ch5 & $\mathrm{H}$ & $\mathrm{H}$ & $\mathrm{H}$ & $\mathrm{H}$ & $\mathrm{H}$ & $\mathrm{H}$ & $\mathrm{OCH}_{3}$ & 18.8 & \\
\hline Ch6 & $\mathrm{H}$ & $\mathrm{H}$ & $\mathrm{H}$ & $\mathrm{H}$ & $\mathrm{H}$ & $\mathrm{H}$ & $\mathrm{C}_{6} \mathrm{H}_{5}$ & - & \\
\hline $\mathrm{Ch} 7$ & $\mathrm{H}$ & $\mathrm{H}$ & $\mathrm{H}$ & $\mathrm{H}$ & $\mathrm{H}$ & $\mathrm{Cl}$ & $\mathrm{Cl}$ & 44.9 & 17.5 \\
\hline Ch8 & $\mathrm{H}$ & $\mathrm{H}$ & $\mathrm{H}$ & $\mathrm{H}$ & $\mathrm{H}$ & $\mathrm{Br}$ & $\mathrm{OCH}_{3}$ & 40.5 & 23.1 \\
\hline Ch9 & $\mathrm{OH}$ & $\mathrm{H}$ & $\mathrm{H}$ & $\mathrm{H}$ & $\mathrm{H}$ & $\mathrm{Br}$ & $\mathrm{H}$ & 44.5 & 18.0 \\
\hline Ch10 & $\mathrm{OH}$ & $\mathrm{H}$ & $\mathrm{H}$ & $\mathrm{H}$ & $\mathrm{H}$ & $\mathrm{H}$ & $\mathrm{SCH}_{3}$ & - & \\
\hline Ch11 & $\mathrm{OH}$ & $\mathrm{H}$ & $\mathrm{H}$ & $\mathrm{H}$ & $\mathrm{H}$ & $\mathrm{H}$ & $\mathrm{OCF}_{3}$ & 24.7 & \\
\hline Ch12 & $\mathrm{OH}$ & $\mathrm{H}$ & $\mathrm{H}$ & $\mathrm{H}$ & $\mathrm{OCH}_{3}$ & $\mathrm{OCH}_{3}$ & $\mathrm{H}$ & 21.6 & \\
\hline Ch13 & $\mathrm{OH}$ & $\mathrm{H}$ & $\mathrm{H}$ & $\mathrm{H}$ & $\mathrm{H}$ & $\mathrm{OCH}_{3}$ & $\mathrm{OCH}_{3}$ & 36.0 & \\
\hline Ch14 & $\mathrm{OH}$ & $\mathrm{H}$ & $\mathrm{H}$ & $\mathrm{H}$ & $\mathrm{OCH}_{3}$ & $\mathrm{H}$ & $\mathrm{OCH}_{3}$ & - & \\
\hline Ch15 & $\mathrm{OCH}_{3}$ & $\mathrm{H}$ & $\mathrm{H}$ & $\mathrm{H}$ & $\mathrm{H}$ & $\mathrm{Cl}$ & $\mathrm{Cl}$ & 90.3 & 7.1 \\
\hline Ch16 & $\mathrm{H}$ & $\mathrm{OCH}_{3}$ & $\mathrm{H}$ & $\mathrm{H}$ & $\mathrm{H}$ & $\mathrm{Cl}$ & $\mathrm{Cl}$ & 43.1 & 19.4 \\
\hline Ch17 & $\mathrm{OH}$ & $\mathrm{OCH}_{3}$ & $\mathrm{H}$ & $\mathrm{H}$ & $\mathrm{H}$ & $\mathrm{H}$ & $\mathrm{H}$ & - & \\
\hline Ch18 & $\mathrm{OH}$ & $\mathrm{OCH}_{3}$ & $\mathrm{H}$ & $\mathrm{H}$ & $\mathrm{H}$ & $\mathrm{H}$ & $\mathrm{Br}$ & - & \\
\hline Ch19 & $\mathrm{OH}$ & $\mathrm{OCH}_{3}$ & $\mathrm{H}$ & $\mathrm{H}$ & $\mathrm{H}$ & $\mathrm{H}$ & $\mathrm{Cl}$ & - & \\
\hline Ch20 & $\mathrm{OH}$ & $\mathrm{OCH}_{3}$ & $\mathrm{H}$ & $\mathrm{H}$ & $\mathrm{H}$ & $\mathrm{H}$ & $\mathrm{CH}_{3}$ & - & \\
\hline $\mathrm{Ch} 21$ & $\mathrm{OH}$ & $\mathrm{OCH}_{3}$ & $\mathrm{H}$ & $\mathrm{H}$ & $\mathrm{H}$ & $\mathrm{H}$ & $\mathrm{OCH}_{3}$ & - & \\
\hline $\mathrm{Ch} 22$ & $\mathrm{OH}$ & $\mathrm{OCH}_{3}$ & $\mathrm{H}$ & $\mathrm{H}$ & $\mathrm{H}$ & $\mathrm{H}$ & $\mathrm{SCH}_{3}$ & 23.6 & \\
\hline $\mathrm{Ch} 23$ & $\mathrm{OH}$ & $\mathrm{OCH}_{3}$ & $\mathrm{H}$ & $\mathrm{H}$ & $\mathrm{H}$ & $\mathrm{Cl}$ & $\mathrm{Cl}$ & 55.3 & 15.3 \\
\hline $\mathrm{Ch} 24$ & $\mathrm{OH}$ & $\mathrm{OCH}_{3}$ & $\mathrm{H}$ & $\mathrm{H}$ & $\mathrm{OCH}_{3}$ & $\mathrm{OCH}_{3}$ & $\mathrm{H}$ & 23.8 & \\
\hline $\mathrm{Ch} 25$ & $\mathrm{OH}$ & $\mathrm{OCH}_{3}$ & $\mathrm{H}$ & $\mathrm{H}$ & $\mathrm{H}$ & $\mathrm{OCH}_{3}$ & $\mathrm{OCH}_{3}$ & 47.3 & 19.9 \\
\hline $\mathrm{Ch} 26$ & $\mathrm{OH}$ & $\mathrm{OCH}_{3}$ & $\mathrm{H}$ & $\mathrm{H}$ & $\mathrm{OCH}_{3}$ & $\mathrm{H}$ & $\mathrm{OCH}_{3}$ & 37.3 & \\
\hline $\mathrm{Ch} 27$ & $\mathrm{OH}$ & $\mathrm{H}$ & $\mathrm{OCH}_{3}$ & $\mathrm{H}$ & $\mathrm{H}$ & $\mathrm{H}$ & $\mathrm{Cl}$ & - & \\
\hline Ch28 & $\mathrm{OH}$ & $\mathrm{H}$ & $\mathrm{OCH}_{3}$ & $\mathrm{H}$ & $\mathrm{H}$ & $\mathrm{Cl}$ & $\mathrm{Cl}$ & - & \\
\hline Ch29 & $\mathrm{OH}$ & $\mathrm{H}$ & $\mathrm{H}$ & $\mathrm{OCH}_{3}$ & $\mathrm{H}$ & $\mathrm{H}$ & $\mathrm{H}$ & 65.6 & 9.6 \\
\hline Ch30 & $\mathrm{OH}$ & $\mathrm{H}$ & $\mathrm{H}$ & $\mathrm{OCH}_{3}$ & $\mathrm{H}$ & $\mathrm{H}$ & $\mathrm{Br}$ & 35.5 & \\
\hline Ch31 & $\mathrm{OH}$ & $\mathrm{H}$ & $\mathrm{H}$ & $\mathrm{OCH}_{3}$ & $\mathrm{H}$ & $\mathrm{Br}$ & $\mathrm{H}$ & 80.9 & 7.8 \\
\hline Ch32 & $\mathrm{OH}$ & $\mathrm{H}$ & $\mathrm{H}$ & $\mathrm{OCH}_{3}$ & $\mathrm{H}$ & $\mathrm{H}$ & $\mathrm{Cl}$ & 39.8 & 17.9 \\
\hline Ch33 & $\mathrm{OH}$ & $\mathrm{H}$ & $\mathrm{H}$ & $\mathrm{OCH}_{3}$ & $\mathrm{H}$ & $\mathrm{H}$ & $\mathrm{CH}_{3}$ & 28.8 & \\
\hline Ch34 & $\mathrm{OH}$ & $\mathrm{H}$ & $\mathrm{H}$ & $\mathrm{OCH}_{3}$ & $\mathrm{H}$ & $\mathrm{H}$ & $\mathrm{OCH}_{3}$ & - & \\
\hline Ch35 & $\mathrm{OH}$ & $\mathrm{OCH}_{3}$ & $\mathrm{H}$ & $\mathrm{OCH}_{3}$ & $\mathrm{H}$ & $\mathrm{H}$ & $\mathrm{H}$ & 70.6 & 9.6 \\
\hline Ch36 & $\mathrm{OH}$ & $\mathrm{OCH}_{3}$ & $\mathrm{H}$ & $\mathrm{OCH}_{3}$ & $\mathrm{H}$ & $\mathrm{H}$ & $\mathrm{Br}$ & 26.2 & \\
\hline Ch37 & $\mathrm{OH}$ & $\mathrm{OCH}_{3}$ & $\mathrm{H}$ & $\mathrm{OCH}_{3}$ & $\mathrm{H}$ & $\mathrm{Br}$ & $\mathrm{H}$ & 61.8 & 11.8 \\
\hline Ch38 & $\mathrm{OH}$ & $\mathrm{OCH}_{3}$ & $\mathrm{H}$ & $\mathrm{OCH}_{3}$ & $\mathrm{H}$ & $\mathrm{H}$ & $\mathrm{Cl}$ & 18.0 & \\
\hline Ch39 & $\mathrm{OH}$ & $\mathrm{OCH}_{3}$ & $\mathrm{H}$ & $\mathrm{OCH}_{3}$ & $\mathrm{H}$ & $\mathrm{H}$ & $\mathrm{CH}_{3}$ & - & \\
\hline $\mathrm{Ch} 40$ & $\mathrm{OH}$ & $\mathrm{OCH}_{3}$ & $\mathrm{H}$ & $\mathrm{OCH}_{3}$ & $\mathrm{H}$ & $\mathrm{H}$ & $\mathrm{OCH}_{3}$ & - & \\
\hline $\mathrm{Ch} 41$ & $\mathrm{OH}$ & $\mathrm{OCH}_{3}$ & $\mathrm{H}$ & $\mathrm{OCH}_{3}$ & $\mathrm{H}$ & $\mathrm{Cl}$ & $\mathrm{Cl}$ & 42.5 & 17.3 \\
\hline AMT & & & & & & & & 90.0 & 0.1 \\
\hline
\end{tabular}

a) at $10 \mu \mathrm{M}, b)$ no or less than $15 \%$ inhibition, $c$ ) arithmetic means were represented here from duplicate experiments.

a significant inhibition at $10 \mu \mathrm{m}$, while the same compound was active at $10-30 \mu \mathrm{M}$. $\left.{ }^{9}\right)$ The discrepancy in the results may be due to the difference of LPS concentrations used in RAW cells $(1 \mu \mathrm{g} / \mathrm{ml} v s .0 .1 \mu \mathrm{g} / \mathrm{ml})$.

In order to pursue the cellular mechanism of the inhibition of NO production, the most potent chalcones (Ch15, Ch31, Ch35) among the derivatives were selected for further study. Ch1 was used as a negative reference compound. When the expression level of iNOS protein in the cells was examined by Western blotting, Ch15 and Ch31 clearly suppressed iNOS induction at $10 \mu \mathrm{M}$ (Fig. 3A). As expected, Ch1 was inactive. Unexpectedly, however, Ch35 did not reduce the level of iNOS expression at the concentrations of up to $20 \mu \mathrm{M}$. RTPCR analysis of iNOS mRNA level supported these findings that Ch15 and Ch31 strongly inhibited iNOS expression, while iNOS mRNA level was only weakly reduced by $\mathrm{Ch} 35$ (Fig. 3B). Therefore, it is reasonably thought that the inhibition of iNOS-catalyzed NO production by $\mathrm{Ch} 15$ and $\mathrm{Ch} 31$ may be at least in part due to the down-regulation of iNOS. But the cellular mechanism of the inhibitory action of $\mathrm{Ch} 35$ could not be explained by iNOS down-regulating capacity. In order to prove the possibility of direct inhibitory activity of Ch35 against iNOS, RAW 264.7 cells were preactivated with LPS to fully induce iNOS without the test compounds for $24 \mathrm{~h}$; and Ch35 and other chalcones were added to the washed RAW cells. After another $24 \mathrm{~h}$, NO levels reflecting iNOS activity were measured. As demonstrated in Table 2, Ch15, Ch31 and Ch35 more or less inhibited NO production at the concentration ranges over $5-20 \mu \mathrm{M}$, while Ch1 did not. Although the potencies of inhibitions were far less than 


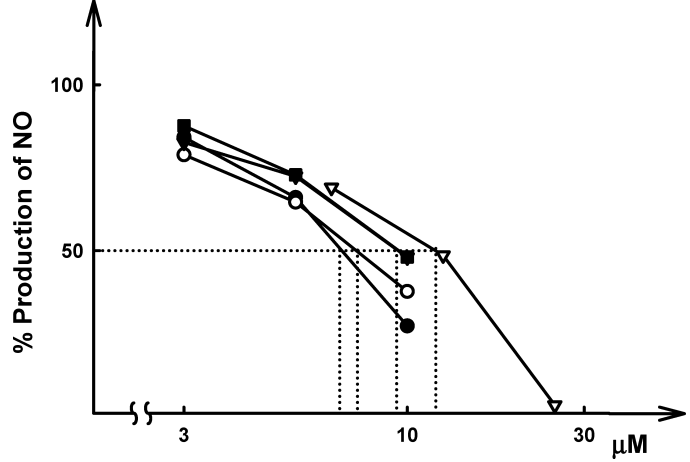

Fig. 1. The Concentration-Dependent Inhibition of iNOS-Catalyzed NO Production by Some Selected Synthetic Chalcones

All chalcone derivatives were dissolved initially in DMSO and diluted with serumfree media on the day of the experiment. Control groups also received the same amount of DMSO. NO concentration of the LPS-treated control group was $31.0 \mu \mathrm{m}$ (Basal level

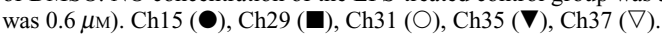

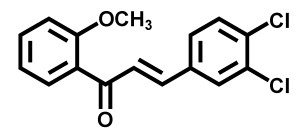

Ch15

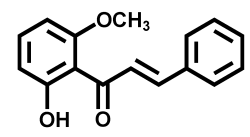

Ch29<smiles>COc1cccc(O)c1C(=O)/C=C/c1cccc(Br)c1</smiles>

Ch31

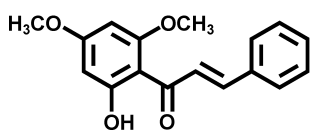

Ch35

Fig. 2. The Chalcone Derivatives Showing Potent Inhibitory Activity of iNOS-Catalyzed NO Production

those of NO inhibition by simultaneous addition with LPS (Fig. 1), it was evident that these chalcones including Ch35 inhibited NO production by pre-induced iNOS, most probably via direct iNOS inhibition. The iNOS inhibitory activities of Ch15 and Ch35 were also proved by the results of enzyme level study to inhibit iNOS when the homogenate of pre-activated RAW cells was used as an enzyme source (data not shown). These results may explain at least partly the inhibitory mechanism of NO production by $\mathrm{Ch} 35$, iNOS inhibition. Therefore, it is clear that certain chalcones tested in the present investigation inhibit iNOS-catalyzed NO production by different mechanisms depending on the chemical structures. Next, the effects of the iNOS down-regulating chalcones (Ch15, Ch31) were examined on NF- $\kappa$ B activation since the transcription factor, especially NF- $\kappa \mathrm{B}$, is known to be crucially involved in iNOS expression from LPS-treated RAW 264.7 cells. Electrophoretic mobility shift assay (Fig. $3 \mathrm{C})$ has shown that $\mathrm{Ch} 15$ and $\mathrm{Ch} 31$ inhibited the NF- $\kappa \mathrm{B}$ activation while $\mathrm{Ch} 35$ did not as had been expected. This finding might indicate that $\mathrm{Ch} 15$ and $\mathrm{Ch} 31$ down-regulated iNOS expression possibly by interrupting the NF- $\kappa$ B activation.

There have been several previous investigations showing
(A)
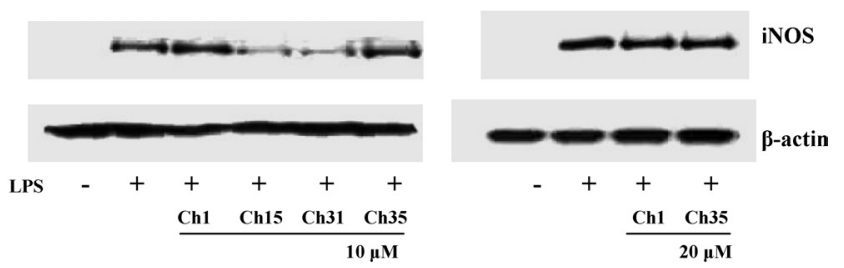

(B)

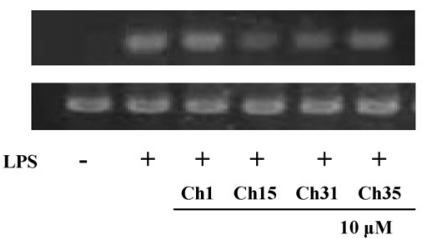

iNOS

G3PDH

(C)

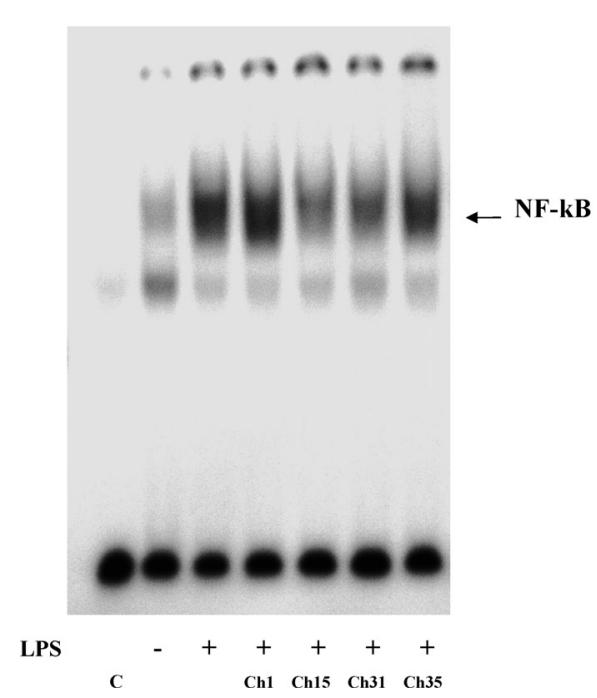

Fig. 3. Effects of the Selected Compounds on the Expression of iNOS and $\mathrm{NF}-\kappa \mathrm{B}$ Activation

(A) Western blotting analysis of iNOS expression. The cells were harvested in the presence/absence of LPS and the test compounds after $20 \mathrm{~h}$ incubation. (B) RT-PCR analysis of iNOS mRNA. The cells were harvested in the presence/absence of LPS and the test compounds after $5 \mathrm{~h}$ incubation. (C) Electrophoretic mobility shift assay. The cells were harvested in the presence/absence of LPS and the test compound after 30 min incubation. Competitor (C).

Table 2. Inhibition of NO Production by Pre-induced iNOS from LPSTreated RAW 264.7 Cells by Some Synthetic Chalcones

\begin{tabular}{crc}
\hline \hline Compounds & Conc. $(\mu \mathrm{M})$ & \% inhibition \\
\hline \multirow{2}{*}{ AMT } & 1 & 70.0 \\
& 10 & 93.8 \\
& 5 & - \\
& 10 & - \\
Ch15 & 20 & - \\
& 5 & 14.0 \\
& 10 & 33.4 \\
Ch31 & 20 & 41.2 \\
& 5 & 11.8 \\
& 10 & 31.8 \\
Ch35 & 20 & 44.5 \\
& 5 & 9.2 \\
& 10 & 30.8 \\
& 20 & 45.5 \\
\hline
\end{tabular}


the iNOS down-regulating capacity of the chalcones. $3^{\prime}, 4^{\prime}, 5^{\prime}, 3,4,5$-Hexamethoxychalcone was found to be iNOS down-regulatory. ${ }^{5)}$ Broussochalcone A was an effective suppressor of iNOS from LPS-treated macrophages. ${ }^{6)}$ Some dimethylaminochalcones potently inhibited iNOS induction. ${ }^{7)}$ Isoliquiritigenin suppressed iNOS expression from LPStreated RAW cells. ${ }^{8)} 2^{\prime}$-hydroxy-4'-methoxychalcone, 2',4dihydroxy-4'-methoxychalcone, 2',4-dihydroxy-6'-methoxychalcone inhibited NO production by down-regulating iNOS expression at high concentration $(30 \mu \mathrm{M})$. These compounds were also demonstrated to inhibit NF- $\kappa$ B and AP-1 activation. ${ }^{9)}$ It is also worth mentioning that the structurally similar chalcone, cardamonin $\left(2^{\prime}, 4^{\prime}\right.$-dihydroxy-6' -methoxychalcone), was recently reported to inhibit iNOS expression by inhibiting the NF- $\kappa \mathrm{B}$ activation. ${ }^{11)}$ Although all these previous studies have shown that some chalcones showed the inhibition of NO production and iNOS down-regulation, the present study has merits in that the optimum chemical structures are suggested. Furthermore, it is proved that, even in the chalcone derivatives having similar chemical structures, the cellular action mechanisms are quite different: the chalcones such as Ch1 were inactive, some other chalcones including Ch15, Ch31 and Ch35 inhibited iNOS-catalyzed NO production. Among the compounds, the chalcones such as Ch15 were proved to be iNOS down-regulators as well as iNOS inhibitors, while Ch35 was an iNOS inhibitor. Ch15 and Ch31 inhibited the NF- $\kappa \mathrm{B}$ activation. The detailed chemical structures required for these properties need to be elucidated further.

It is also important to note that several synthetic hydroxychalcones having 2' and/or 4-hydroxyl group such as 4-hydroxychalcone inhibited cell-surface expression of VCAM-1, while the substitution with 2-hydroxyl group or methoxyl group reduced the suppressive effects of the corresponding chalcones. ${ }^{17)}$ Phloretin suppresses the stimulated expression of endothelial adhesion molecules. ${ }^{18)}$ All this regulatory activity of proinflammatory molecules including iNOS by certain chalcones may contribute to their anti-inflammatory activity.

In conclusion, the present investigation has clearly shown that certain chalcone derivatives inhibited iNOS-catalyzed NO production from LPS-treated RAW 264.7 cells. The most potent ones among the test compounds were Ch15, Ch29, Ch31 and $\mathrm{Ch} 35$. The favorable chemical structures were found to be a methoxyl substitution in A-ring at an adjacent position $\left(2^{\prime}\right.$ or $\left.6^{\prime}\right)$ to carbonyl moiety with/without $2^{\prime}$-(or $6^{\prime}$-)hydroxyl group in A-ring and 3-halogen substitution in B-ring. It was also found that they inhibited NO production by different cellular mechanisms depending on the chemical structures. Some chalcones such as Ch15 showed NO inhibitory activity at least in part by iNOS down-regulation as well as iNOS inhibition. Others like Ch35 inhibited NO production at least in part by iNOS inhibition, but not by iNOS down-regulation. In particular, Ch15 and Ch31 down-regulated iNOS expression possibly by suppressing the NF- $\kappa \mathrm{B}$ activation. These chalcone derivatives may be used as the lead molecules for developing new anti-inflammatory agents.

Acknowledgements This research was financially supported by research grant No. R01-2004-000-10134-0 from the Basic Research Program of the Korea Science \& Engineering Foundation and post-BK21 program. Equipment at the Institute of Pharmaceutical Science (Kangwon National University) was used for this study.

\section{REFERENCES}

1) Gabor M., "Plant Flavonoids in Biology and Medicine: Biochemical, pharmacological, and structure-activity relationships," ed. by Cody V., Middleton E., Harborne J. B., Alan R. Liss, New York, 1986, pp. $471-480$.

2) Middleton E., Kandaswami C., Theoharides T. C., Pharmacol. Rev., 52, 673-751 (2000)

3) Kim H. P., Son K. H., Chang H. W., Kang S. S., J. Pharmacol. Sci., 96, $229-245$ (2004).

4) Tinker A. C., Wallace A. V., Curr. Topics Med. Chem., 6, 77-92 (2006).

5) Herencia F., Ferrandiz M. L., Ubeda A., Guillen I., Dominguez J. N., Charris J. E., Lobo G. M., Alcaraz M. J., FEBS Lett., 453, 129-134 (1999).

6) Cheng Z.-J., Lin C.-N., Hwang T.-L., Teng C.-M., Biochem. Pharmacol., 61, 939-946 (2001).

7) Rojas J., Dominguez J. N., Charris J. E., Lobo G., Paya M., Ferrandiz M. L., Eur. J. Med. Chem., 37, 699-705 (2002).

8) Takahashi T. T., Takasuka N., Ligo M., Baba M., Nishino H., Tsuda H., Okuyama T., Cancer Sci., 95, 448-453 (2004).

9) Ban H. S., Suzuki K., Lim S. S., Jung S. H., Lee S., Ji J., Lee H. S., Lee Y. S., Shin K. H., Okuchi K., Biochem. Pharmacol., 67, 15491557 (2004).

10) Won S.-J., Liu C.-T., Tsao L.-T., Weng J.-R., Ko H.-H., Wang J.-P., Lin C.-N., Eur. J. Med. Chem., 40, 103-112 (2005).

11) Israf D. A., Khaizurin T. A., Syhida A., Lajis N. H., Khozirah S., Mol. Immunol., 44, 673-679 (2006).

12) Dao T. T., Chi Y. S., Kim J., Kim H. P., Kim S., Park H., Bioorg. Med. Chem. Lett., 14, 1165-1167 (2004).

13) Chi Y. S., Cheon B. S., Kim H. P., Biochem. Pharmacol., 61, 11951203 (2001).

14) Mossman T., J. Immunol. Methods, 65, 55-63 (1983).

15) Kim H., Lee H. S., Chang K. T., Ko T. H., Baek K. J., Kwon N. S., J. Immunol., 154, 4741-4748 (1995).

16) Lin C.-N., Lee T.-H., Hsu M.-F., Wang J.-P., Ko F.-N., Teng C.-M., J. Pharm. Pharmacol., 49, 530-536 (1997).

17) Tanaka S., Sakata Y., Morimoto K., Tambe Y., Watanabe Y., Honda G., Tabata M., Oshima T., Masuda T., Umezaw T., Shimada M., Nagakura N., Kamisako W., Kashiwada Y., Ikeshiro Y., Planta Med., 67, 108 113 (2001).

18) Stangl V., Lorenz M., Ludwig A., Grimbo N., Guether C., Sanad W., Ziemer S., Martus P., Baumann G., Stangl K., J. Nutr., 135, 172-178 (2005). 